\title{
Parasitic copepods from Egyptian Red Sea fishes: Bomolochidae Claus, 1875
}

\author{
Hoda Hassan El-Rashidy • Geoffrey Allan Boxshall
}

Received: 5 November 2015/Accepted: 26 November 2015

(C) The Author(s) 2015. This article is published with open access at Springerlink.com

\begin{abstract}
Two species of parasitic copepods from the genus Bomolochus von Nordmann, 1832 (Cyclopoida: Bomolochidae) are redescribed in detail, based on material collected from the gills of Red Sea fishes. Host material was caught at El-tor, near Sharm El-Sheikh, and in the Gulf of Suez, Egypt. Both sexes of Bomolochus bellones Burmeister, 1835 were collected from the gills of a needlefish Tylosurus choram (Rüppell) caught in the Gulf of Suez. This is a new host record. The female is well characterised so only the male is described. Adult females of Bomolochus minus Lin \& Ho, 2005 were obtained from the branchial cavities and gills of mojarra Gerres oyena (Forsskål). This species was known only from its original description in Taiwan, and this report constitutes a new host record and a significant range extension. Both parasite species are new records for Egyptian Red Sea waters.
\end{abstract}

H. H. El-Rashidy

Department of Oceanography, Faculty of Science,

Alexandria University, Moharram Bey, Alexandria, Egypt

G. A. Boxshall $(\square)$

Department of Life Sciences, Natural History Museum, Cromwell Road, London SW 7 5BD, UK

e-mail: g.boxshall@nhm.ac.uk

\section{Introduction}

The family Bomolochidae Claus, 1875 currently comprises about 141 species of parasites which commonly inhabit the branchial chamber and gills of their marine fish hosts (Boxshall \& Halsey, 2004). The type genus, Bomolochus von Nordmann, 1832, is the second largest in the family and the review of Ho \& Lin (2009) recognised 20 species as valid. Two species are reported here, Bomolochus bellones Burmeister, 1835 and B. minus Lin \& Ho, 2005.

Bomolochus bellones was originally discovered off Helgoland, Germany by Burmeister (1835) as a parasite on Belone belone (L.) (as Esox bellone L.), and was subsequently reported from north-western European waters and the Mediterranean (see Vervoort, 1962; Kabata, 1979). However, it was Cressey \& Collette (1970) who first documented the worldwide range of this parasite: they collected hundreds of specimens of B. bellones from the gill chambers and oral valves of 16 species of needlefishes (family Belonidae) collected from numerous localities across the North and South Atlantic, the Indian Ocean, and the North and South Pacific (including off Australia). They were the first to report $B$. bellones from the Red Sea, on Ablennes hians (Valenciennes), but they did not find this parasite on Tylosurus choram (Rüppell). Burmeister's original description (Burmeister, 1835) was rather rudimentary, but the adult female of $B$. bellones has subsequently been redescribed by numerous authors including Vervoort (1962), Cressey \& 
Collette (1970), Kabata (1979) and Ho et al. (1983). The female is well characterised. However, the only description available of the male is that of Hartmann (1870) who provided a single illustration of an undissected male in ventral view. In the present work, the male $B$. bellones is described in detail, based on material obtained from Tylosurus choram caught in the Gulf of Suez.

The only previous report of $B$. minus is the original description based on material from five different host fishes landed in Taiwan (Lin \& Ho, 2005). This species is very closely related to the poorly described species, B. indicus Kaliyamurthy, Singh \& Singh, 1988 and may even be a junior synonym. The females from Egyptian waters are redescribed here to add to the body of morphological knowledge that will provide the evidence which will allow such questions of possible synonymy to be addressed.

\section{Materials and methods}

Host fish were purchased from local markets and examined for the presence of parasitic copepods. Copepods were removed from the host and preserved in $70 \%$ ethanol. The copepods were dissected and mounted in lactophenol as temporary slide preparations and examined on an Olympus microscope. Measurements were made using an ocular micrometer and drawings were made with the aid of drawing tube. Morphological terminology follows Huys \& Boxshall (1991). Host names were validated against FishBase (Froese \& Pauly, 2015).

\section{Family Bomolochidae Sumpf, 1871 Bomolochus von Nordmann, 1832}

\section{Bomolochus bellones Burmeister, 1835}

Syns Parabomolochus bellones (Burmeister, 1835); Bomolochus ardeolae Krøyer, 1863; Artacolax ardeolae (Krøyer, 1863); Holobomolochus ardeolae (Krøyer, 1863); Bomolochus concinnus Wilson, 1911; Parabomolochus concinnus (Wilson, 1911); Bomolochus hemirhamphi Pillai, 1965; Parabomolochus hemirhamphi (Pillai, 1965); Bomolochus hyporhamphi Yamaguti \& Yamasu, 1959; Parabomolochus hyporhamphi (Yamaguti \& Yamasu, 1959); Pseudartacolax hyporhamphi (Yamaguti \& Yamasu, 1959); Bomolochus tumidus
Shiino, 1957; Parabomolochus tumidus (Shiino, 1957); Artacolax tumidus (Shiino, 1957)

Host: Tylosurus choram (Rüppell).

Locality: Gulf of Suez (Red Sea), Egypt.

Site on host: Gills, branchial cavity.

Material examined: 25 adult females and 2 males.

\section{Description (Figs. 1-2)}

Adult male. Body cyclopiform (Fig. 1A); 0.87-0.98 (0.93) $\mathrm{mm}$ long (based on 2 specimens). Prosome length $\quad 0.46-0.54 \quad(0.50) \mathrm{mm}$, maximum width 0.28-0.35 (0.31) mm; comprising cephalothorax incorporating first pedigerous somite, and free second to fourth pedigerous somites. Urosome (Fig. 1A, B) length $0.37-0.44(0.41) \mathrm{mm}$; comprising fifth pedigerous somite, pear-shaped genital somite and 2 free abdominal somites. Ventral surface of first free abdominal somite ornamented posteriorly with rows of spinules. Anal somite deeply incised, ornamented with transverse patch of spinules anteriorly and paired patches posteriorly (Fig. 1B). Caudal rami (Fig. 1B) ornamented with ventral patch of spinules.

Antennule (Fig. 1C) 7-segmented; proximal 4 segments only slightly more robust than distal 3 cylindrical segments. First segment with 5 robust pilose setae, none modified; second segment with 14 setae ( 6 robust pilose setae, 5 naked setae and 3 short plumose setae); third segment with 1 naked seta and 3 robust pilose setae; fourth segment with 1 naked seta and 2 robust pilose setae. Cylindrical distal segments with setal formula 4, 2+1ae and 7+1ae respectively; distal element on fifth segment longer than in female.

Antenna (Fig. 1D) uniramous, 3-segmented; comprising long proximal segment (coxobasis) bearing single long seta, short middle (= first endopodal) segment armed with small naked seta, and highly ornamented apical segment. Apical segment produced into blunt distal process ornamented with marginal row of blunt spinules continuous with row present along margin of apical segment, ventral surface of segment with multiple rows of hooked spinules. Apical segment armed distally with 4 curved claws, 3 naked setae and pectinate process bearing tiny naked seta.

Labrum (Fig. 1E) ornamented with paired patches of spinules on ventral surface and patches of long setules laterally. Mandible (Fig. 1F) bearing 2 unequal 


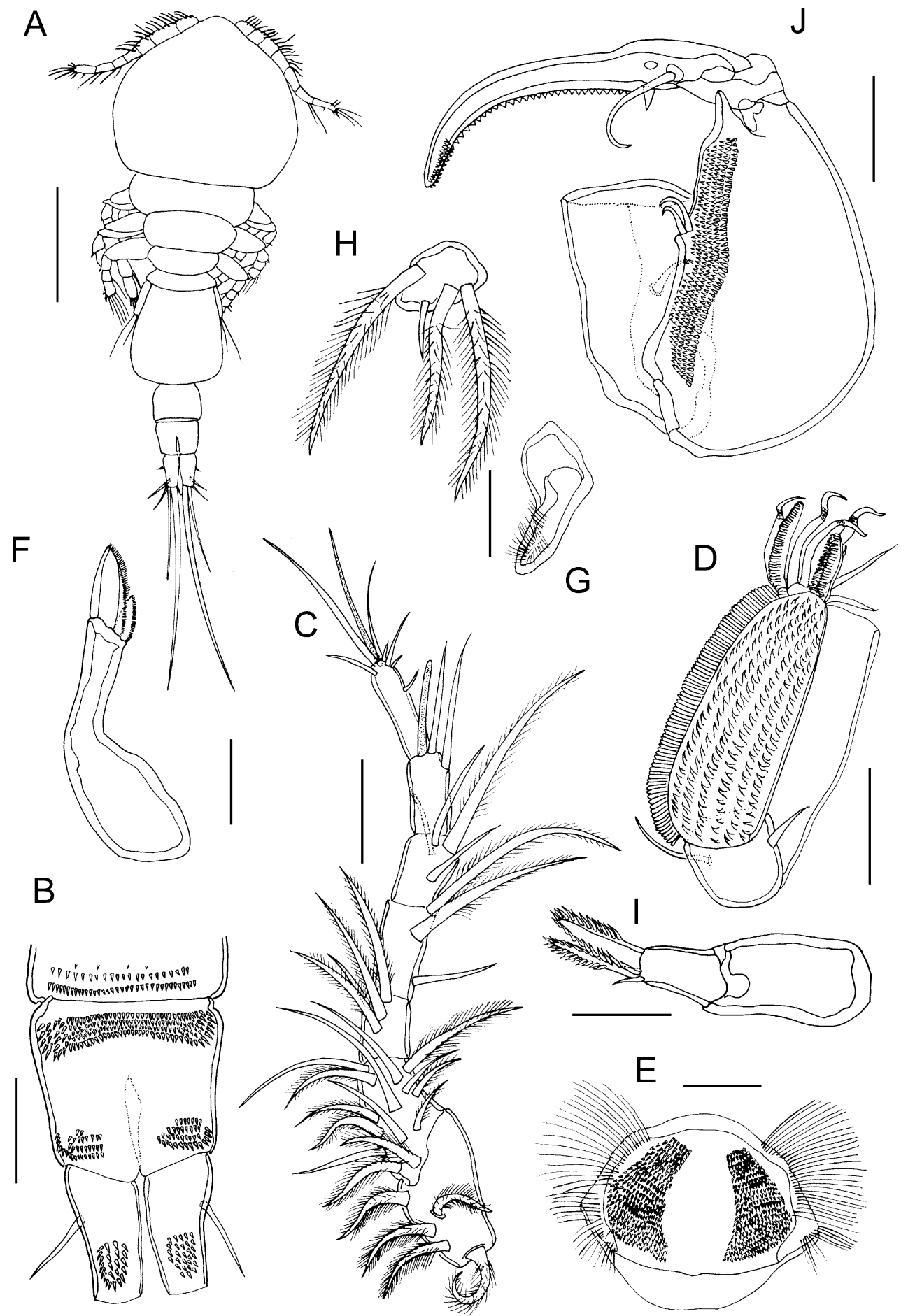

Fig. 1 Bomolochus bellones Burmeister, 1835. Adult male. A, Habitus, dorsal view; B, Anal somite and caudal rami, ventral view; C, Antennule; D, Antenna; E, Labrum; F, Mandible; G, Paragnath; H, Maxillule; I, Maxilla; J, Maxilliped. Scale-bars: A, 0.25 mm; B-D, J, $50 \mu \mathrm{m} ; \mathrm{E}-\mathrm{I}, 25 \mu \mathrm{m}$ 


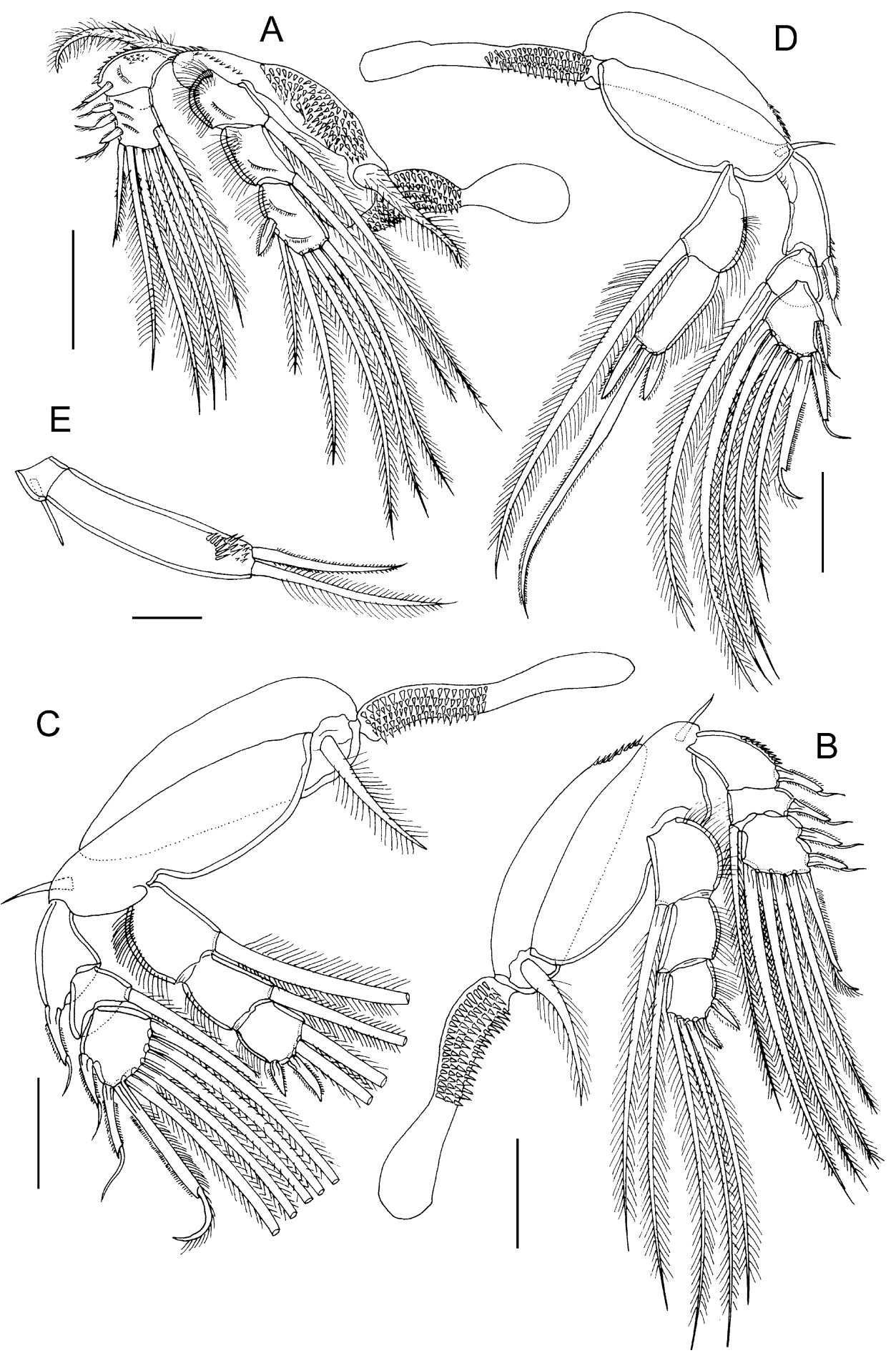

Fig. 2 Bomolochus bellones Burmeister, 1835. Adult male. A, Leg 1; B, Leg 2; C, Leg 3; D, Leg 4; E, Leg 5. Scale-bars: C-D, 100 4m; $\mathrm{A}-\mathrm{B}, 50 \mu \mathrm{m}$; E, $25 \mu \mathrm{m}$ 
blades distally, each spinulate along one margin. Paragnath (Fig. 1G) forming long blunt process fringed distally with long setules. Maxillule (Fig. 1H) forming rounded lobe armed with 1 naked seta and 3 unequal pilose setae. Maxilla (Fig. 1I) 2-segmented; proximal segment (syncoxa) larger, unarmed; second segment (basis) narrowing distally, bearing 2 spinulate apical elements plus small naked seta.

Maxilliped (Fig. 1J) comprising syncoxa armed with naked seta; basis massive, ornamented medially with multiple rows of hooked spinules and armed medially with 2 naked setae; distal claw incorporating endopodal segment, armed with long seta and small hyaline process proximally, inner margin of claw ornamented with row of denticles plus cluster of spinules at tip.

Legs 1 to 4 biramous, with armature as follows:

\begin{tabular}{lllll}
\hline & Coxa & Basis & Exopod & Endopod \\
\hline Leg 1 & $0-1$ & $1-0$ & I-0; III, 1,5 & $0-1 ; 0-1 ;$ I,5 \\
Leg 2 & $0-1$ & $1-0$ & I-0; I-1; II,I,4 & $0-1 ; 0-1 ;$ II,3 \\
Leg 3 & $0-1$ & $1-0$ & I-0; 0-1; II,I,5 & $0-1 ; 0-1 ;$ II,2 \\
Leg 4 & $0-0$ & $1-0$ & I-0; 0-1; II,I,4 & $0-1 ;$ I,1,I \\
\hline
\end{tabular}

Leg 1 (Fig. 2A) rami less flattened and less modified than in female. Protopod ornamented with rows of spinules, armed with plumose outer basal seta and plumose inner seta (not flattened as in female). Interpodal sclerite small, slightly wider than long, ornamented with multiple transverse rows of small spinules (Fig. 2A). Exopod 2-segmented; first segment with one spine at outer distal corner; segments 2 and 3 partially fused ventrally, bearing outer 3 spines, terminal seta, plus 5 inner setae (Fig. 5A). Endopod 3-segmented; all segments ornamented with outer margin setules, first and second segments each with oblique row of small spinules on anterior surface, third segment with 2 rows.

Legs 2 and 3 (Fig. 2B-C) biramous with 3-segmented rami; outer margin spines on exopod segments finely bilaterally spinulate, each spine bearing subterminal flagellum. Ornamentation of long setules present on outer margins of endopodal segments. Coxa of leg 2 with spinules at outer distal angle.

Leg 4 (Fig. 2D) biramous with 3-segmented exopod and 2-segmented endopod; outer margin spines on exopod segments finely bilaterally spinulate, each spine bearing subterminal flagellum. Inner seta on proximal endopodal segment about twice as long as ramus, extending almost to tip of long seta on distal segment; distal endopodal segment with inner apical spine longer than outer; apical seta about 1.5 times longer than ramus. Ornamentation of long setules present on outer margins of endopodal segments. Leg 4 coxa with spinules at outer distal angle.

Leg 5 (Fig. 2E) 2-segmented, protopodal segment small armed with outer seta; free distal segment (exopod) ornamented distally with patches of spinules, armed with 2 unequal terminal setae.

\section{Remarks}

In the 180 years since its discovery, Bomolochus bellones has acquired a long synonymy. It became the type-species of the genus Parabomolochus erected in 1962 by Vervoort (1962), but just seven years later Vervoort (1969) synonymised Parabomolochus with Bomolochus and transferred B. bellones back under its original binomen. Five other nominal species have been recognised as junior subjective synonyms of $B$. bellones. Cressey (1981) re-examined the type-material of Bomolochus ardeolae Krøyer, 1863 from Platybelone argalus (LeSueur) (as Belone ardeola LeSueur), and concluded that it was a synonym of $B$. bellones. Until Cressey (1981) examined the types, confusion had surrounded the identity of Bomolochus ardeolae, exacerbated by the publication of Wilson (1908) who mistakenly identified and described material from Hypsypops rubicunda (Girard), caught off California, under the name $B$. ardeolae. The material of Wilson (1908) was subsequently reidentified as Holobomolochus glyphysodontis (Krøyer, 1863) by Cressey (1981). As pointed out by Cressey (1981), the genus Artacolax Wilson, 1908 was established with Bomolochus ardeolae as its typespecies, so Artacolax is a synonym of Bomolochus.

Cressey (1983) also re-examined the type-material of Bomolochus concinnus Wilson, 1911, collected from Strongylura marina (Walbaum) (as Tylosurus marinus) (Wilson, 1911), and considered that it was conspecific with B. bellones. Bere (1936) reported $B$. nitidus Wilson, 1911 from Strongylura timиси (Walbaum) (as Strongylura timuca) caught off the west coast of Florida (USA). Pillai (1967) considered this to be a misidentification, noting strong differences between Bere's material and the original description of B. nitidus given by Wilson (1911). Pillai (1967) 
Table 1 Known hosts of Bomolochus bellones Burmeister, 1835

\begin{tabular}{|c|c|c|}
\hline Host family/ species & Parasite & Reference \\
\hline \multicolumn{3}{|l|}{ Belonidae } \\
\hline Ablennes hians (Valenciennes) & $\begin{array}{l}\text { Parabomolochus bellones (Burmeister, } \\
\text { 1835) }\end{array}$ & Cressey \& Collette (1970) \\
\hline \multirow[t]{2}{*}{ (as Tylosurus schismatorhynchus) } & Bomolochus tumidus Shiino, 1957 & Shiino (1957) \\
\hline & $\begin{array}{l}\text { Bomolochus hyporhamphi Yamaguti \& } \\
\text { Yamasu, } 1959\end{array}$ & Yamaguti \& Yamasu (1959) \\
\hline \multirow[t]{2}{*}{$\begin{array}{l}\text { Belone belone (Linnaeus) } \\
\text { (as } B . \text { vulgaris, } B . \text { rostrata or Esox } \\
\text { bellones) }\end{array}$} & Bomolochus bellones Burmeister, 1835 & $\begin{array}{l}\text { Burmeister (1835); Heller (1865); } \\
\text { Hartmann (1870); } \\
\text { Brian (1902, 1906); Leigh-Sharpe (1933); } \\
\text { Kabata (1979); Vervoort (1962) }\end{array}$ \\
\hline & $\begin{array}{l}\text { Parabomolochus bellones (Burmeister, } \\
\text { 1835) }\end{array}$ & Cressey \& Collette (1970) \\
\hline Belone svetovidovi Collette \& Parin & $\begin{array}{l}\text { Parabomolochus bellones (Burmeister, } \\
\text { 1835) }\end{array}$ & Cressey \& Collette (1970) \\
\hline Platybelone argalus (LeSueur) & $\begin{array}{l}\text { Parabomolochus bellones (Burmeister, } \\
\text { 1835) }\end{array}$ & Cressey \& Collette (1970) \\
\hline (as Belone ardeola) & Bomolochus ardeolae Krøyer, 1863 & Krøyer (1863) \\
\hline $\begin{array}{l}\text { Strongylura anastomella } \\
\text { (Valenciennes) }\end{array}$ & $\begin{array}{l}\text { Parabomolochus bellones (Burmeister, } \\
\text { 1835) }\end{array}$ & Cressey \& Collette (1970) \\
\hline Strongylura incisa (Valenciennes) & $\begin{array}{l}\text { Parabomolochus bellones (Burmeister, } \\
\text { 1835) }\end{array}$ & Cressey \& Collette (1970) \\
\hline Strongylura leiura (Bleeker) & $\begin{array}{l}\text { Parabomolochus bellones (Burmeister, } \\
\text { 1835) }\end{array}$ & Cressey \& Collette (1970) \\
\hline \multirow[t]{2}{*}{ Strongylura marina (Walbaum) } & Bomolochus concinnus Wilson C. B., 1911 & Wilson (1911) \\
\hline & $\begin{array}{l}\text { Parabomolochus bellones (Burmeister, } \\
\text { 1835) }\end{array}$ & Cressey \& Collette (1970) \\
\hline Strongylura notate (Poey) & $\begin{array}{l}\text { Parabomolochus bellones (Burmeister, } \\
\text { 1835) }\end{array}$ & Cressey \& Collette (1970) \\
\hline $\begin{array}{l}\text { Strongylura senegalensis } \\
\quad \text { (Valenciennes) }\end{array}$ & $\begin{array}{l}\text { Parabomolochus bellones (Burmeister, } \\
\text { 1835) }\end{array}$ & Cressey \& Collette (1970) \\
\hline Strongylura strongylura (van Hasselt) & $\begin{array}{l}\text { Parabomolochus bellones (Burmeister, } \\
\text { 1835) }\end{array}$ & Cressey \& Collette (1970) \\
\hline \multirow[t]{2}{*}{ Strongylura tiтиси (Walbaum) } & Bomolochus nitidus Wilson C. B., 1911 & Bere (1936) \\
\hline & $\begin{array}{l}\text { Parabomolochus bellones (Burmeister, } \\
\text { 1835) }\end{array}$ & Cressey \& Collette (1970) \\
\hline Strongylura urvillii (Valenciennes) & $\begin{array}{l}\text { Parabomolochus bellones (Burmeister, } \\
\text { 1835) }\end{array}$ & Cressey \& Collette (1970) \\
\hline Tylosurus acus (Lacépède) & $\begin{array}{l}\text { Parabomolochus bellones (Burmeister, } \\
\text { 1835) }\end{array}$ & Cressey \& Collette (1970) \\
\hline Tylosurus choram (Rüppell) & Bomolochus bellones Burmeister, 1835 & Present account \\
\hline $\begin{array}{l}\text { Tylosurus crocodilus (Pèron \& } \\
\text { LeSueur) }\end{array}$ & $\begin{array}{l}\text { Parabomolochus bellones (Burmeister, } \\
\text { 1835) }\end{array}$ & Cressey \& Collette (1970) \\
\hline $\begin{array}{l}\text { Tylosurus gavialoides Castlenau } \\
\text { (as Lhotskia gavialoides) }\end{array}$ & $\begin{array}{l}\text { Parabomolochus bellones (Burmeister, } \\
\text { 1835) }\end{array}$ & Cressey \& Collette (1970) \\
\hline \multicolumn{3}{|l|}{ Hemiramphidae } \\
\hline Hemiramphus far (Forsskål) & Bomolochus hemirhamphi Pillai, 1965 & Pillai $(1965,1985)$ \\
\hline $\begin{array}{l}\text { Hyporhamphus australis } \\
\text { (Steindachner) }\end{array}$ & Bomolochus bellones Burmeister, 1835 & Collette (1974) \\
\hline
\end{tabular}


Table 1 continued

\begin{tabular}{lll}
\hline Host family/ species & Parasite & Reference \\
\hline $\begin{array}{l}\text { Hyporhamphus melanochir } \\
\text { (Valenciennes) }\end{array}$ & Bomolochus bellones Burmeister, 1835 & Collette (1974) \\
$\begin{array}{l}\text { Hyporhamphus regularis (Günther) } \\
\text { Hyporhamphus sajori (Temminck \& } \\
\text { Schlegel) }\end{array}$ & $\begin{array}{l}\text { Bomolochus bellones Burmeister, 1835 } \\
\text { Bomolochus hyporhamphi Yamaguti \& }\end{array}$ & Collette (1974) \\
& Yamasu, 1959 & Yamaguti \& Yamasu (1959) \\
$\begin{array}{l}\text { Scomberesocidae } \\
\text { Cololabis saira (Brevoort) }\end{array}$ & Bomolochus tumidus Shiino, 1957 & Shiino (1957) \\
\hline
\end{tabular}

suggested that Bere's material was conspecific with $B$. concinnus Wilson, 1911 which Cressey (1983) had placed in synonymy with B. bellones. Bomolochus nitidus Wilson, 1911 is a valid species (Ho \& Lin, 2009) parasitic on mugilids.

In 1983, Ho et al. (1983) concluded that three IndoWest Pacific species, B. tumidus Shiino, 1957, B. hyporhamphi Yamaguti \& Yamasu, 1959 and $B$. hemirhamphi Pillai, 1965, were all conspecific with $B$. bellones. Accepting all these synonymies adds several other host species, including halfbeaks (family Hemiramphidae) and the saury (family Scomberesocidae), to the known range of fishes utilised by $B$. bellones. Collette (1974) reported B. bellones from an additional three species of Hyporhamphus (Table 1).

Males of Bomolochus are found and reported less frequently than females. Currently males are known for just seven of the 20 valid species of Bomolochus: B. bellones, B. ensiculus (Cressey, in Cressey \& Collette, 1970), B. globiceps (Vervoort \& Ramirez, 1968), B. megaceros Heller, 1865, B. psettobius (Vervoort, 1962), B. soleae Claus, 1864 and $B$. xenomelanirisi Carvalho, 1955. In addition, Vervoort (1969) described an unidentified male as Bomolochus sp., although this specimen may well have been immature (Vervoort, 1969). The only description of male $B$. bellones is that of Hartmann (1870) which is supported by a single illustration of an undissected male, providing an inadequate level of detail. The detailed description presented here permits comparison with congeneric males.

Adult males of Bomolochus spp. are all smaller than their respective females. Sexual dimorphism is exhibited in urosomal segmentation (the formation of the genital somite and the number of free abdominal somites), in the antennule (the lack of the modified hook-like seta on the proximal segment in the male), the robust subchelate maxilliped of the male, the 2-segmented endopod of leg 4 in the male (3segmented in the female), and the presence of only two setal elements on the free exopodal segment of leg 5 in the male (compared to four setal elements in the female). The spine and setal formula for the exopods of legs 3 and 4 is also sexually dimorphic: adult males lack an outer spine on the second exopodal segment of both legs, whereas a spine is present in the females. There are additional differences in ornamentation: the male has extensive spinulation on the ventral surface of the first free abdominal and anal somites, on the caudal rami, and on the interpodal sclerites of legs 1 to 4. This enhanced spinular ornamentation presumably assists the male in holding the female during mating.

\section{Bomolochus minus Lin \& Ho, 2005}

Host: Gerres oyena (Forsskål).

Locality: El-Tor, Egypt, Red Sea.

Site on host: Gill cavity.

Material examined: 4 females.

Description (Figs. 3-5)

Adult female. Body cyclopiform (Fig. 3A); 1.49 to 1.57 (1.53) mm long (based on 4 specimens); prosome length $0.95-1.06 \quad(1.00) \mathrm{mm}$, maximum width 0.69-0.88 (0.86) $\mathrm{mm}$. Prosome comprising broad cephalothorax and free second to fourth pedigerous somites; third somite not overlapping fourth in dorsal view (Fig. 3A). Cephalothorax bearing pair of acutely pointed tines in rostral area (Fig. 3B). Urosome (Fig. 3C) $0.51-0.60(0.56) \mathrm{mm}$ long, comprising fifth 


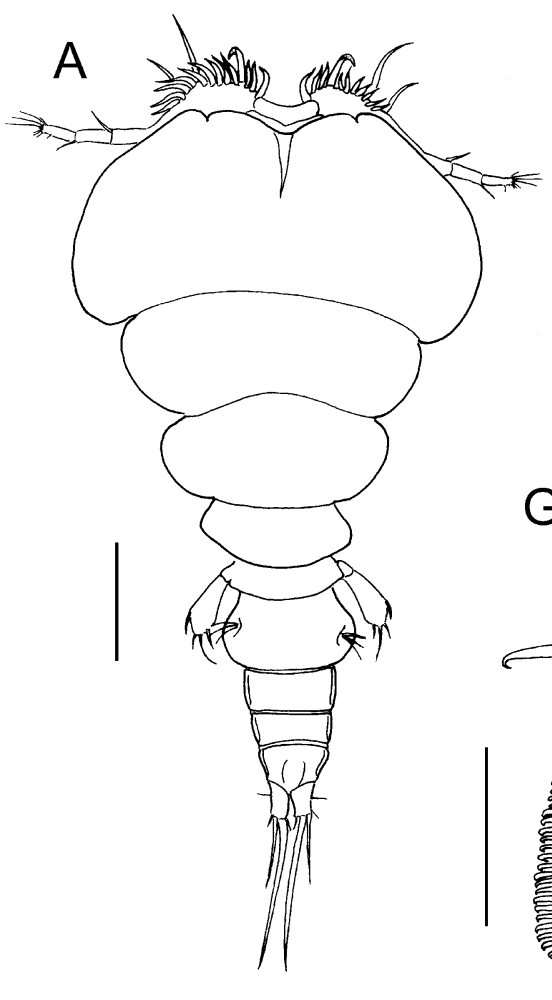

$\mathrm{F}$

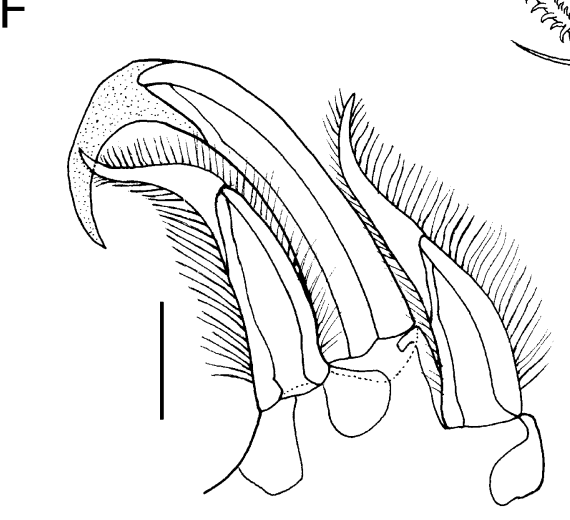

B
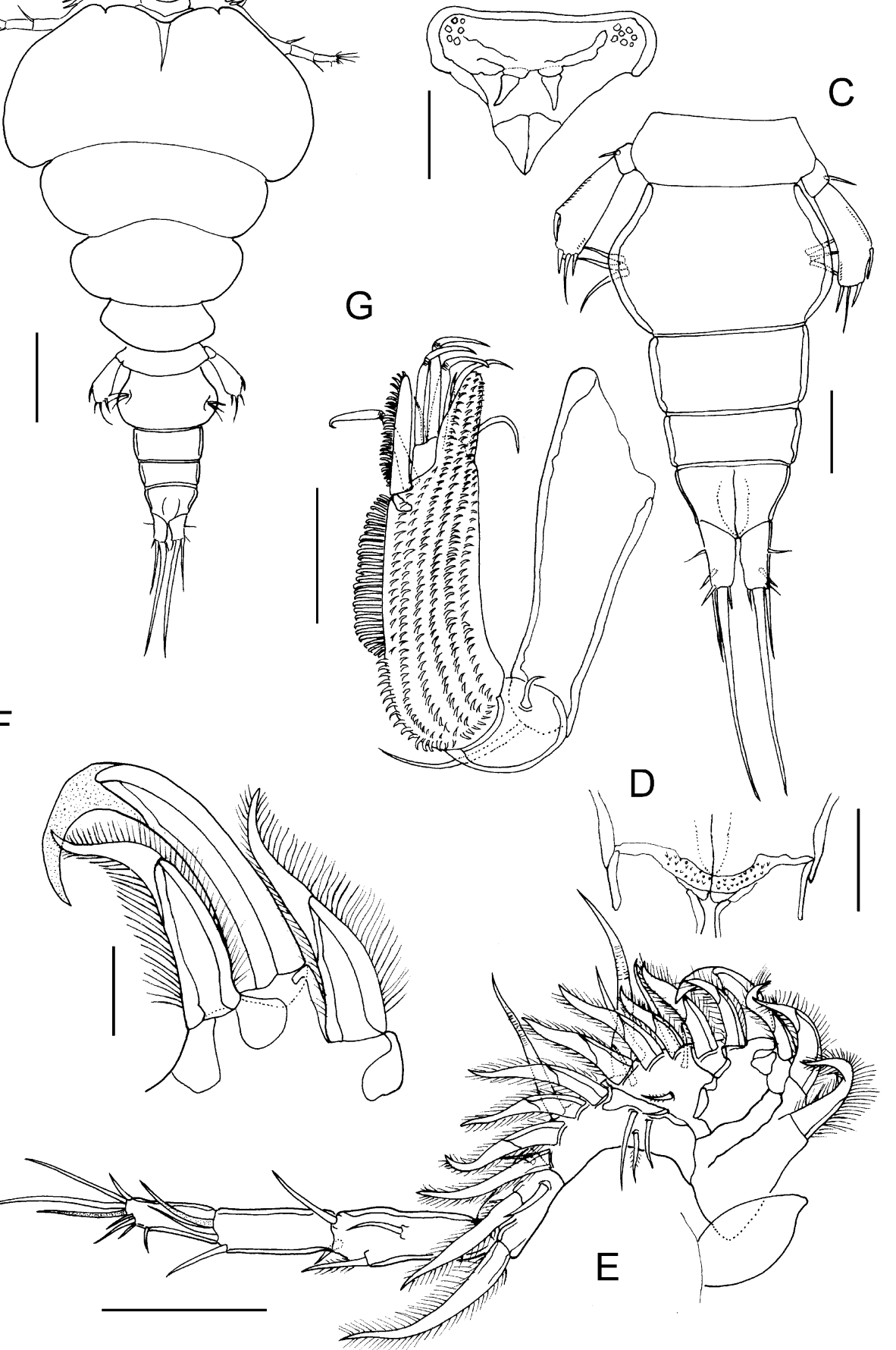

Fig. 3 Bomolochus minus Lin \& Ho, 2005. Adult female. A, Habitus, dorsal view; B, Rostrum, ventral view; C, Urosome; D, Articulation between anal somite and caudal rami; E, Antennule; F, Proximal part of first antennulary segment showing modified fourth seta and adjacent setae; G, Antenna. Scale-bars: A, $250 \mu \mathrm{m}$; C, E, $100 \mu \mathrm{m} ; \mathrm{B}, \mathrm{D}, \mathrm{G}, 50 \mu \mathrm{m} ; \mathrm{F}, 25 \mu \mathrm{m}$ 
pedigerous somite, genital double-somite and 3 free abdominal somites. All urosomites wider than long; second free abdominal somite shortest; anal somite deeply incised posteromedially. Surfaces of all urosomites and caudal rami smooth, lacking ornamentation of spinules, but minute denticles present on membrane between anal somite and caudal rami (Fig. 3D). Caudal rami (Fig. 1C) twice as long as wide, bearing single principal seta, plus 5 small setae.

Antennule (Fig. 3E) comprising heavily sclerotised proximal part and slender distal part; proximal part indistinctly 4-segmented, distal part slender, comprising 3 segments. First segment bearing 5 robust pilose setae, fourth seta modified, hook-shaped, only extending slightly beyond tip of adjacent fifth seta; distal nonchitinised, recurved part of fourth seta about 1/3 length of fifth seta (Fig. 1F). Segments 2 and 3 bearing total of 19 setae ( 8 robust pilose setae, 5 small setae on ventral surface, 6 naked setae of various length on dorsal surface); segment 4 bearing 4 setae ( 2 robust pilose setae, 1 ventral, 1 dorsal naked seta); setal formula of distal part of antennule: $4,2+1$ ae, $7+1$ ae.

Antenna (Fig. 3G) uniramous, 3-segmented; comprising long proximal segment (coxobasis) bearing single long seta, short middle (= first endopodal) segment armed with small naked seta, and highly ornamented apical segment. Apical segment produced into blunt distal process ornamented with rows of spinules ventrally, continuous with multiple rows over ventral surface of segment. Apical segment armed distally with pectinate process, 4 curved claws and 4 naked setae.

Labrum (Fig. 4A) ornamented with 2 large patches of spinules on ventral surface, and irregular rows of long setules along lateral margins. Mandible (Fig. 4B) tipped with 2 unequal blades, each with single spinulate margin. Paragnath (Fig. 4C) elongate, blunt process fringed distally with long setules. Maxillule (Fig. 4D) lobate, armed with 1 naked and 3 unequal pilose setae. Maxilla (Fig. 4E) 2-segmented; proximal segment (syncoxa) larger, unarmed; second segment (basis) narrowing distally, bearing 2 spinulate apical elements plus small naked seta. Maxilliped (Fig. 4F) comprising syncoxa, armed with distal seta; basis armed with 2 pilose setae; terminal (endopodal) segment forming sigmoid claw provided with short accessory process, and bearing pilose seta proximally.
Legs 1 to 4 biramous, with armature as follows:

\begin{tabular}{lllll}
\hline & Coxa & Basis & Exopod & Endopod \\
\hline Leg 1 & $0-1$ & $1-0$ & I-0; IV,1,6 & $0-1 ; 0-1 ;$ I,5 \\
Leg 2 & $0-1$ & $1-0$ & I-0; I-1; III,I,5 & $0-1 ; 0-2 ;$ II,3 \\
Leg 3 & $0-1$ & $1-0$ & I-0; I-1; II,I,5 & $0-1 ; 0-1 ;$ II,2 \\
Leg 4 & $0-0$ & $1-0$ & I-0; I-1; II,I,4 & $0-1 ; 0-1 ;$ I,1,I \\
\hline
\end{tabular}

Leg 1 (Fig. 4G) modified with flattened rami: protopod with plumose basal outer seta; inner coxal seta transformed into flattened element with rounded tip, fringed with long setules; interpodal sclerite (Fig. 4H) slightly longer than wide, ornamented with $\mathrm{V}$-shaped rows of long spinules. Exopod indistinctly 2-segmented; first segment with one large spine at outer distal corner, spine with spinule rows bilaterally (Fig. 4I); compound distal segment bearing 4 outer spines (Fig. 4J), 1 small seta at base of terminal plumose seta, and 6 plumose setae. First and second endopodal segments each with inner seta and ornamented with surface spinules and outer margin setules; third segment with 5 plumose setae, and minute spine located proximal to base of outermost seta (Fig. 4G).

Leg 2 (Fig. 5A-C) with 3-segmented rami; coxa with short inner coxal seta and ornamented with patch of setules at outer distal angle; basis with outer basal seta. All exopodal segments ornamented with patches of flattened scale-like spinules; all outer spines provided with subterminal flagellum; outer spine on first exopodal segment bilaterally spinulate, but outer margins of spines on second and third segments denticulate (Fig. 5A, B). Outer and inner margins of first exopodal segment ornamented with long setules. Endopodal segments very broad and flattened; outer margins of first and second segments ornamented with long setules and distal row of spinules, third segment with outer row of setules. Interpodal sclerite ornamented with row of long spinules.

Leg 3 (Fig. 5D) with 3-segmented rami; coxa and basis with short inner coxal seta and outer basal seta, respectively. Coxa lacking ornamentation at outer distal angle. Exopodal segments armed and ornamented as for leg 2. Endopodal segments less broad and less flattened than in leg 2; ornamentation as for leg 2. Interpodal plate ornamented with row of long spinules. 

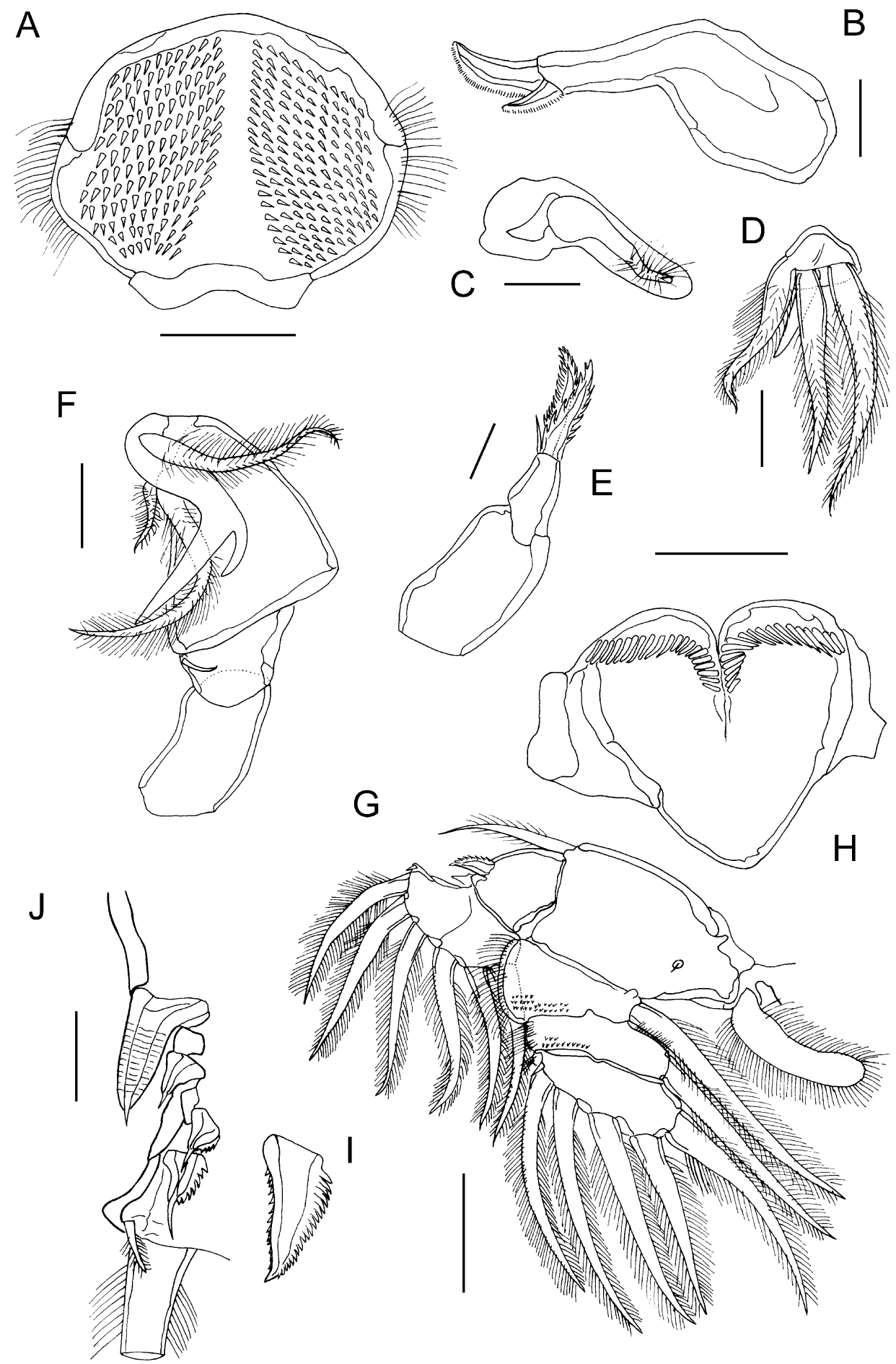

B

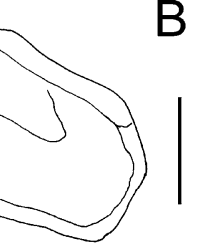




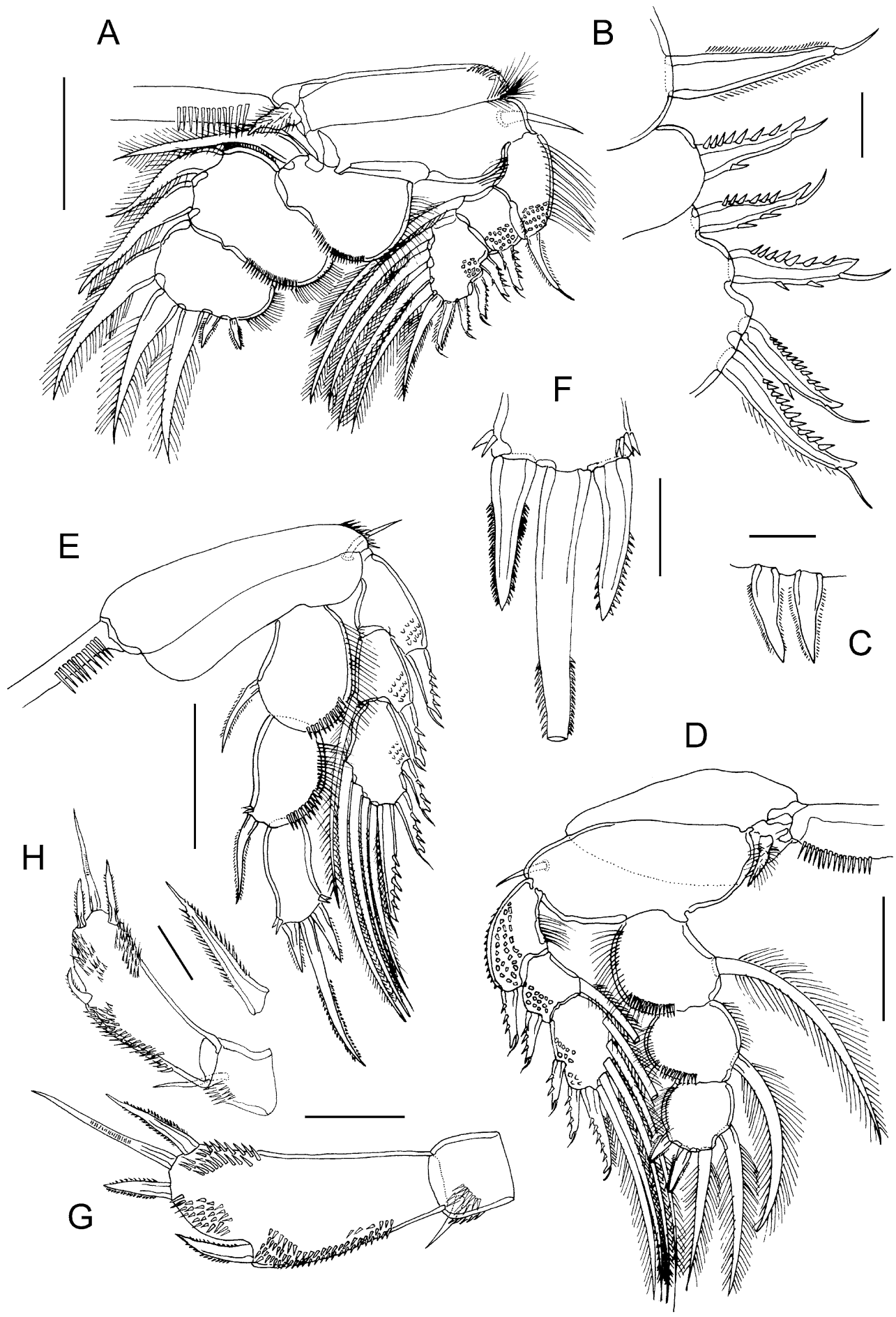

Fig. 5 Bomolochus minus Lin \& Ho, 2005. Adult female. A, Leg 2; B, Outer spines on exopod of leg 2; C, Outer spines on terminal segment of endopod of leg 2; D, Leg 3; E, Leg 4; F, Spines and seta on terminal segment of endopod leg 4; G, Leg 5; H, Leg 5 in another specimen. Scale-bars: A, D-E, $100 \mu \mathrm{m} ; \mathrm{G}, 50 \mu \mathrm{m} ; \mathrm{B}-\mathrm{C}, \mathrm{F}, 25 \mu \mathrm{m}$ 
Leg 4 (Fig. 5E) with 3-segmented rami; coxa lacking inner seta and ornamented with patch of spinules at outer distal angle; basis with outer basal seta. All exopodal segments ornamented with patches of flattened scalelike spinules; all outer spines denticulate and provided with subterminal flagellum (Fig. 5E). Outer margins of first and second endopodal segments ornamented with long setules and distal row of spinules. Inner seta on first endopodal segment short, extending nearly to middle of second segment. Inner seta on second endopodal segment extending to about $75 \%$ length of third segment; small spinules present at base of seta. Third segment with spinules present adjacent to base of outer and inner apical spines. Interpodal sclerite ornamented with row of long spinules.

Leg 5 (Fig. 5G) 2-segmented; protopodal segment small, ornamented with patch of spinules and armed with outer seta; free segment (exopod) armed with subterminal spine extending almost to end of segment, but not extending beyond distal margin (Fig. 5G, H), outer and inner terminal spines, plus naked seta in middle of distal margin; inner distal spine longer than outer (Fig. 5I). Exopod ornamented with patch of spinules extending along outer lateral margin, plus 2 distal patches.

Leg 6 (Fig. 3A) represented by 3 short setae located in egg sac attachment area on genital double-somite.

Male: unknown.

\section{Remarks}

Only four nominal species of Bomolochus share the unusual scale-like ornamentation on the exopods of swimming legs 2 to 4, namely, B. decapteri Yamaguti, 1936, B. indicus Kaliyamurthy, Singh \& Singh, 1988, B. minus and B. unicirrus Brian, 1902. The adult females of two of these species, B. decapteri and $B$. unicirrus, are characterised by the possession of patches of spinules on the ventral surface of both the anal somite and the caudal rami (cf. Yamaguti, 1936: figure 50; Ho \& Rokicki, 1987: figure 1c). Bomolochus minus lacks such patches: indeed, the specific epithet "minus" specifically alludes to the absence of this ornamentation (Lin \& Ho, 2005). Kaliyamurthy et al. (1988) do not mention any such patches of ornamentation on the anal somite or caudal rami, and while the overall quality of their description of B. indicus is low, it does mention the scale-like ornamentation (referred to as "pustules") on the exopods of legs 2 to 4 , indicating that the authors were paying attention to such fine details. So we presume these spinule patches are absent in $B$. indicus also.

Bomolochus indicus and B. minus are morphologically very similar, the body length given for the former $(1.6 \mathrm{~mm})$ lies within the range $(1.52$ to 2.00 $\mathrm{mm}$ ) given for the latter, and both occur on the same host, Gerres filamentosus Cuvier (see Kaliyamurthy et al., 1988; Lin \& Ho, 2005). The former also occurred on a second gerreid, Gerres limbatus Cuvier (as Gerres lucidus), while the latter also occurred on four sciaenids, Johnius belengerii (Cuvier), J. amblycephalus (Bleeker), Pennahia pawak (Lin), and Chrysochir aureus (Richardson). Despite sharing a common suite of characters and co-occurring on the gerreid host, G. filamentosus, these two species were not compared by Lin \& Ho (2005) when they established their new species from Taiwan.

The key to species of Bomolochus created by Ho \& Lin (2009) separates B. indicus and B. minus on the basis of the length of the modified, hook-like fourth seta on the proximal segment of the antennule of the female relative to the length of the adjacent fifth seta. In $B$. indicus the fourth seta protrudes well beyond the tip of the fifth seta, whilst in B. minus it does not. The interpretation of this character can be difficult as relative lengths can appear to vary according to the angle of observation: for example, in Lin \& Ho's description (Lin \& Ho, 2005) the dorsal view of the adult female of $B$. minus shows the fourth seta as markedly longer than the fifth, but in the ventral view of the antennule, they appear similar in length. In the Egyptian material the fourth seta is somewhat intermediate in length: in Fig. 3F the enlargement of the third, fourth and fifth setae, the hook-like fourth seta is shown extending a small distance beyond the tip of the fifth seta. On the basis of this character we identify the Egyptian material from Gerres oyena as B. minus, but we recommend that the $B$. indicus is fully redescribed to modern standards because we consider it possible that these two Bomolochus species are conspecific.

\section{Compliance with ethical standards}

Conflict of interest The authors declare that they have no conflict of interest.

Ethical approval All applicable institutional, national and international guidelines for the care and use of animals were followed. 
Open Access This article is distributed under the terms of the Creative Commons Attribution 4.0 International License (http:// creativecommons.org/licenses/by/4.0/), which permits unrestricted use, distribution, and reproduction in any medium, provided you give appropriate credit to the original author(s) and the source, provide a link to the Creative Commons license, and indicate if changes were made.

\section{References}

Bere, R. (1936). Parasitic copepods from Gulf of Mexico fish. American Midland Naturalist, 17, 577-625.

Boxshall, G. A., \& Halsey, S. H. (2004). An introduction to copepod diversity. The Ray Society, London, $966 \mathrm{pp}$.

Brian, A. (1902). Note sui alcuni crostacei parassiti dei pesci del Mediterraneo. Atti della Società Ligustica di Scienze Naturali e Geografiche, 13, 30-45.

Brian, A. (1906). Copepodi parassiti dei pesci d'Italia. Genova, $187 \mathrm{pp}, 21 \mathrm{pls}$.

Burmeister, H. (1835). Beschreibung einiger neuen oder weniger bekannten Schmarotzerkrebse, nebst allgemeinen Betrachtungen über die Gruppe, welche sie angehören. Nova Acta Physico-Medica Academia Caesarea Leopoldino-Carolina, 17 (1), 269-336, pls 23, 24, 24A, 25.

Collette, B. B. (1974). The Garfishes (Hemiramphidae) of Australia and New Zealand. Records of the Australian Museum, 29, 11-105.

Cressey, R. F. (1981). Parasitic copepods from the Gulf of Mexico and Caribbean Sea, I: Holobomolochus and Neobomolochus. Smithsonian Contributions to Zoology, $339,1-24$.

Cressey, R. F. (1983). Parasitic copepods from the Gulf of Mexico and Caribbean Sea, II: Bomolochidae. Smithsonian Contributions to Zoology, 389, 1-35.

Cressey, R. F., \& Collette, B. B. (1970). Copepods and needlefishes: A study in host parasite relationships. Fishery Bulletin of the National Oceanic and Atmospheric Administration, United States, 63, 347-432.

Froese, R., \& Pauly, D. (Eds) (2015). FishBase. World Wide Web electronic publication, www.fishbase.org (accessed on 05 November 2015).

Hartmann, R. (1870). Beiträge zur anatomischen Kenntnis der Schmarotzerkrebse. 1. Ueber Bomolochus belones Burm. Archiv für Anatomie, Physiologie, und wissenschaftliche Medizin, 1870, 116-158, pls. 3-4.

Heller, C. (1865). Reise der Österreichischen Fregatte Novara um die Erde in den Jahren 1857-58- 59 unter den Befehlen des Commodore B. Von Wuellerstorf-Urbair. Zoologischer Theil, zweiter Band, dritte Abtheilung, Crustaceen. Vienna, $280 \mathrm{pp}$.

Ho, J.-S., Do, T. T., \& Kashahara, S. (1983). Copepods of the family Bomolochidae parasitic on fishes of Kojima Bay, Okayama Prefecture. Journal of the Faculty of Applied Fisheries, 22, 1-41.

Ho, J.-S., \& Lin, C.-L. (2009). Bomolochus bramus n. sp. (Copepoda, Poecilostomatoida, Bomolochidae) from the pomfrets (Bramidae) off Taiwan, with a list of nominal species and key to valid species of Bomolochus von Nordmann, 1832. Zootaxa, 2092, 47-57.

Ho, J.-S., \& Rokicki, J. (1987). Poecilostomatoid copepods parasitic on fishes off the west coast of Africa. Journal of Natural History, 21, 1025-1034.

Huys, R., \& Boxshall, G. A. (1991). Copepod Evolution. The Ray Society, London, 468 pp.

Kabata, Z. (1979). Parasitic Copepoda of British fishes. The Ray Society, London, 468 pp.

Kaliyamurthy, M., Singh, S. K., \& Singh, S. B. (1988). Bomolochus indicus sp. nov. (Copepoda) parasitic on the fishes of the Pulicat Lake. Proceedings of the National Academy of Science, India, 58 (B), 399-402.

Krøyer, H. (1863). Bidrag til Kundskab om Snyltekrebsene. Naturhistorisk Tidsskrift, (3)2, 75-426, pls. 1-18.

Leigh-Sharpe, W. H. (1933). A second list of parasitic Copepoda of Plymouth, with a description of three new species. Parasitology, 25, 113-118.

Lin, C.-L., \& Ho, J.-S. (2005). Three species of Bomolochus Claus, 1864 (Copepoda: Bomolochidae) parasitic on marine fishes of Taiwan. Journal of the Fisheries Society of Taiwan, 32(2), 113-128.

Pillai, N. K. (1965). Copepods parasitic on South Indian fishes: family Bomolochidae-3. Journal of the Bombay Natural History Society, 62, 38-55.

Pillai, N. K. (1967). Redescription of seven species of Bomolochids from the collections of the United States National Museum. Journal of the Marine Biological Association of India, 7, 243-269.

Pillai, N. K. (1985). Copepod Parasites of Marine Fishes. In: The Fauna of India. Calcutta: Zoological Society of India, 900 pp.

Shiino, S. M. (1957). Copepods parasitic on Japanese fishes, 16. Bomolochidae and Taeniacanthidae. Reports of the Faculty of Fisheries, Prefectural University of Mie, 2(3), 411-428.

Vervoort, W. (1962). A review of the genera and species of the Bomolochidae (Crustacea, Copepoda), including the description of some old and new species. Zoologische Verhandelingen, Leiden, 56, 1-111.

Vervoort, W. (1969). Caribbean Bomolochidae (Copepoda: Cyclopoida). Studies on the Fauna of Curaçao and other Caribbean Islands, 28(105), 1-125.

Wilson, C. B. (1908). North American parasitic copepods: a list of those found upon the fishes of the Pacific coast, with descriptions of new genera and species. Proceedings of the United States National Museum, 35(1652), 431-481.

Wilson, C. B. (1911). North American parasitic copepods belonging to the family Ergasilidae. Proceedings of the United States National Museum, 39(1788), 263-400.

Yamaguti, S. (1936). Parasitic copepods from fishes of Japan. Part 1. Cyclopoida 1. Kyoto Imperial University, Published by author, 8 pp, 5 pls.

Yamaguti, S., \& Yamasu, T. (1959). Parasitic copepods from fishes of Japan with description of 26 new species and remarks on two known species. Biological Journal of Okayama University, 5(3-4), 89-165. 